\title{
Transnational and Organized Crime in Oceania
}

ARTICLE in SSRN ELECTRONIC JOURNAL · AUGUST 2012

DOI: $10.2139 /$ ssrn.2122002

DOWNLOADS

125

3 AUTHORS, INCLUDING:

Roderic G. Broadhurst

Australian National University

97 PUBLICATIONS 342 CITATIONS

SEE PROFILE
VIEWS

49

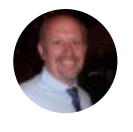

Mark Adam Lauchs

Queensland University of Technology

22 PUBLICATIONS 15 CITATIONS

SEE PROFILE 


\section{Transnational and Organized Crime in Oceania}

Roderic Broadhurst, Australian National University

Mark Lauchs, Queensland University of Technology

Sally Lohrisch, Queensland University of Technology

Forthcoming in .'Transnational Crime in Oceania', in Jay Albanese and Paul Reichel, Eds. Transnational Crime, Sage, NY

\section{Introduction}

This chapter briefly outlines the context and nature of transnational crime within the large and diverse region of Oceania. The region encompasses over 8.5 million square kilometres (or 3.3 million square miles), and is comprised of 25 island nations with varied histories, cultures, economies, and political and legal systems. Oceania can be broadly divided into four geographical regions: Australia (including Norfolk Island) and New Zealand, Melanesia (Fiji, New Caledonia, Papua New Guinea, Solomon Islands, Vanuatu), Micronesia (Guam, Kiribati, Marshall Islands, Federated States of Micronesia, Nauru, Northern Mariana Islands, Palau) and Polynesia (American Samoa, Cook Islands, French Polynesia, Niue, Pitcairn, Samoa, Tokelau, Tonga, Tuvalu, Wallis and Futuna Islands). ${ }^{1}$ Australia is the largest nation in the region, both in terms of population and geographical size, followed by Papua New Guinea and New Zealand. The umbrella term 'Pacific Island Countries' (PICs) is used to describe the numerous nations of the Pacific Ocean; here we use PIC to refer to the island nations comprising Micronesia, Melanesia and Polynesia (except New Zealand and Hawaii). ${ }^{2}$

Australia and New Zealand are the most economically significant nations in the region. They share many legal, economic and political similarities as former British colonies and dominions, having inherited the common law and Westminster systems. Australia is the largest economy in Oceania, with a population of over 22 million and an annual GDP of \$1.6 trillion. It is a nation of mature and stable political, legal and economic systems. New Zealand has 4.3 million residents and a GDP of $\$ 127$ billion. Papua New Guinea, the only other large nation in Oceania, has 6.6 million people but its GDP is only $\$ 9.5$ billion.

\footnotetext{
${ }^{1}$ Note: The above geographical divisions are those used by the United Nations Statistical Division; they may not reflect all geographical understandings of the region.

${ }^{2}$ New Zealand is discussed separately from the PICs due to its distinct historical background that has influenced its contemporary economic, political and legal systems. Hawaii is not discussed in this chapter due to its political affiliation with United States.
} 
Australia's GDP per capita in 2011 was over $\$ 40,000$, New Zealand's $\$ 27,000$, but the next highest is Fiji with $\$ 4,600$. Thus most of the PICs have both small populations and developing economies. The quality of governance also varies greatly across the region. Transparency International's Corruption Perceptions Index 2011 (Transparency International, 2011), which ranks countries by their perceived levels of corruption, shows Oceania's diversity of governance with Australia and New Zealand ranked as having low risks of corruption, whereas the Solomon Islands and Papua New Guinea ranked among the highest risk. New Zealand was ranked at number 1 (indicating the lowest risk) in the Index out of 159 countries. After Australia (which was ranked at number 8), the next Oceanic country Samoa was ranked at 69. The remaining nations rate among countries with the highest perceived risk of corruption, with Tonga at 95, Solomon Islands 120 and Papua New Guinea at 154.

Australia maintains a relatively large immigrant intake, including from its neighbour New Zealand, and to a lesser extent, the other nations of Oceania. Consequently, it has a diverse ethnic population with the migrant community constituting a fifth of its total population; the highest proportion of any country with a population of 20 million or greater (United Nations, n.d.). In both Australia and NZ the migrant population exceeds the indigenous Aboriginal and Maori population. This is not the case among the PICs where indigenous populations pre-dominate, however, in Fiji where about $38 \%$ of the population is of Indian origin.

The PICs are made up of 20,000 to 30,000 islands, some as small as coral atolls, scattered throughout the Pacific Ocean. Large parts of the Pacific Islands are geographically isolated, sparsely populated and vulnerable to natural disasters (McCusker, 2006, p. 1).

These nations have varied histories and distinct cultures and societies. Language is diverse throughout the region and within States. For example 841 languages are found in Papua New Guinea (PNG), 63 languages are found in the Solomon Islands, and in Vanuatu over 100 tribal languages. Political and legal systems also differ in the region from monarchies, to military juntas and democracies. In addition, many of the PICs are viewed as 'emerging States'; that is, they are experiencing ongoing economic, political and legal instability resulting from recent independence from European colonial powers, which is exacerbated by the ongoing effects of globalization (AFP, 2006; Browne, 2006). 
Given these factors the region has been described as the 'arc of instability' (AFP, 2006). Examples of political instability in the region include Fiji, which has experienced four coups in the last quarter century, a number of constitutional crises and continued instability. ${ }^{3}$ The Solomon Islands have also been destabilised by a coup and civil war and an Australian and New Zealand led peacekeeping and stabilization mission has been in place since 2003 (see Regional Assistance Mission to Solomon Islands). A constitutional crisis has also unfolded in PNG in 2011-2012 with a failed mutiny of elements of the PNG Defence Forces, and the arrest of the Chief Justice arising from conflict between groups in support of rival premiers (Fox, 2012). Generally political instability has manifested itself in poor governance and corruption in several jurisdictions in the region. There is also significant economic underdevelopment, with high rates of unemployment and concerns regarding appropriate fiscal management (including suitable public sector controls, development of private sector industries and opportunities, appropriate aid management and regional integration) (Browne, 2006). These underlying political and socioeconomic weaknesses are vulnerabilities that have also been exploited by criminal entrepreneurs.

Unemployment rates are very high in the PICs, running at $70 \%$ of youth and $80 \%$ of males across the islands (SFADTRC, 2010, pp. 7-8). While there is disagreement by observers as to whether unemployment will lead to increases in crime rates (SFADTRC, 2010, p. 10) increased urbanization and inequality are known drivers of crime (Newman, 1999). Ethnic tensions are also high across the region. PNG experiences frequent inter tribal conflicts, especially in the volatile highlands and other PICs, such as Fiji, see clashes between indigenous and migrant Chinese and Indian communities (SFADTRC, 2010, p. 12).

Oceania is not a major global economic or trade hub. However, its importance is growing with the economic shift towards the Asia Pacific region and the contemporary emergence of a multi-polar model of global political and economic power (UNODC, 2011b, p. 43). Indeed, Oceania is potentially an important region, strategically situated near the global power-house economies of China and India, whilst also having strong ties to traditional powers such as the United States, and the United Kingdom. Australia the regional middle power in particular, retains strong economic links with both traditional and

\footnotetext{
${ }^{3}$ The four coup d'états in Fiji occurred in May and September 1987, 2000 and 2006. The most recent constitutional crises occurred in 2009 when an Indian led political party won most seats in the legislature precipitating the closure of parliament by the mainly indigenous Fiji Armed Forces in 2006. Fiji remains under military rule although elections are to be held in 2014.
} 
emerging economies, and is one of China's leading trading partners while retaining strong alliance with the United States.

Australia and New Zealand's high GDP makes them attractive markets for drug, vice, money laundering and other contraband associated with criminal activity. The PICs lack both the money and population to become significant criminal markets. Nonetheless they play a special role in the criminal environment as transit points and safe operational bases for transnational criminal activity - offering the "comparative advantage in illegality" (Windybank, 2008, p. 32).

\section{Organized Crime Groups}

The reporting of organized crime in Oceania varies according to the levels of development in the different nations, thus there is more information about Australia than the rest of the region. In 2004, the Australian Crime Commission identified 97 organized crime groups in Australia, most of which operate in Sydney and Melbourne (Broadhurst, Gordon, \& McFarlane, 2012). Traditionally the PICs see little serious organized crime, however, "evidence is often anecdotal, contradictory, or fragmented. Drug seizures, for instance, provide some information on how drug traffickers operate, but the real extent of the problem remains unknown." (Windybank, 2008, p. 33) Transnational crime networks are more likely to operate in the PICs because of these nations' low levels of development, poverty and instability However, cultural and ethnic differences across the region preclude any consistency in how criminal groups operate (McCusker, 2006, p. 2). The forms of transnational crime that has been identified in the PICs appears to be facilitated by the increasing role of foreign investment and influence in PNG and other resource rich countries of the region, rather than indigenous crime groups transcending cultural, linguistic and ethnic differences in the PICs. Investors mainly from East Asia (primarily the People's Republic of China (PRC) and Taiwan) and India (AFP, 2005) may also bring in their wake triad-like groups. Despite the lack of reliable information it is possible to identify some key players in Oceania transnational crime.

\section{Outlaw Motorcycle Gangs}

Outlaw motorcycle gangs (OMCGs) operate throughout Australia and New Zealand. OMCGs such as the Rebels, Finks, Hells Angels, are recognised as an organized crime threat (Australian Crime Commission (ACC), 2012) and have attracted increased attention from law enforcement. Since their establishment in Australia and New Zealand in the 1960s (PJCACC, 2007, p. 8; Veno \& Gannon, 2010, p. 24), OMCGs have evolved from motorcycle enthusiast clubs into significant participants in illicit/criminal markets (ACC, 
2011). The extent of the organized crime threat that OMCGs pose is unclear (PJCACC, 2007, pp. 22-27; Veno \& van den Eynde, 2008) but some Australian OMCGs have links with OMCGs in the USA, Canada and Scandinavia who are involved in significant criminal enterprises. Whether OMCGs are primarily established for criminal purposes or whether the structures and interpersonal associations of the OMCGs simply facilitate criminal activity (Barker, 2011) has created challenges for effective countermeasures. Nevertheless the visibility and profile of the OMCGs shows they play a major role among the criminal macro-networks (Spapens, 2010) that facilitate serious crime in Australia and New Zealand. Recent high profile homicides involving competing OMCGs prompted South Australia and NSW, for example to introduced association or consorting laws to help suppress these group. Generally a range of law reforms focusing on serious and organized crime have been enacted in Australia to address witness protection, tainted wealth and the interception of communications (see Ayling and Broadhurst 2012a for details).

Some OMCGs spread to Australia and New Zealand as part of the franchising of the gangs by American organisers and through the absorption of local home-grown gangs. In fact, New Zealand was the first international location outside the United States that the Hell's Angels established a chapter (Veno \& Gannon, 2010). However, despite this international connection, the operations of OMCGs at the local chapter level are largely autonomous with strategic direction from the national leadership (ACC, 2011; CMC, n.d.). Australia has chapters of the 'Big Four' OMCGs - the Hell's Angels, Bandidos, Outlaws and Pagans (Quinn \& Forsyth, 2011). Australia also has 'home-grown' OMCGs, such as the Rebels, Finks and Coffin Cheaters, who are not aligned with an international brand, but have been established and operate within Australia (Veno \& Gannon, 2010, p. 70). Recent reports indicate the Rebels, Australia's largest OMCG, is establishing chapters in New Zealand (Oakes, 2012; OFCANZ, 2011; Robertson, 2012). There are also reports that show that some OMCGs have been establishing chapters and more permanent connections throughout SE Asia, notably in Thailand (Oakes, 2012, Robertson 2011).

It is estimated there are about 40 active OMCGs in Australia (Veno \& Gannon, 2010, p. 56); however there is uncertainty about the precise numbers of chapters and 'patched' members. There are between 100-200 chapters of the large clubs (ACC, 2012; Veno \& Gannon, 2010, p. 56). Estimates of total OMCG membership range from between 2500 (Veno \& Gannon, 2010, p. 57) to 4000 (ACC, 2011). These diverging numbers reflect the difficulty in ascertaining membership numbers and/or actual shifts in membership (through attrition or recruitment variations etc.). Once exclusively Caucasian the OMCGs 
have diversified to include Middle Eastern ethnic groups and Pacific Islanders and do business with Chinese organized crime groups (Ayling \& Broadhurst, 2012a) .

Members of these OMCGs are thought to engage in a broad spectrum of criminal activities from drug trafficking (especially the domestic production of amphetamines and cannabis), money laundering, fraud and identity crime, firearms offences (including firearms trafficking), extortion, vehicle-related crime (primarily vehicle re-birthing) and prostitution. Membership of these OMCGs is often used as 'leverage' to further these activities through enhanced criminal associations and networks. These groups also engage in the legitimate economy and have infiltrated the maritime, private security, entertainment, natural resources and construction industries (ACC, 2011).

\section{Other Groups}

Traditional mafia groups are rare in Oceania. There is evidence of 'Ndrangheta and other Italian mafialike groups in Australia and some indication that Taiwan or PRC based triad-like groups such as the 'Four Seas' operate in Fiji and PNG. These groups seek to exploit the relative vulnerability of PICs. A few reports refer to these groups as 'Triads' or 'Mafia' (Bashir, 2010; Callick, 2010) whilst others note them to simply be groups of 'Chinese nationals'. Whatever their origin and structure, these groups corrupt officials to obtain work permits, visas, investment approvals, and passports to facilitate their movement (AFP, 2006, p. 6). The three main criminal industries in the region are narco-trafficking, people trafficking and firearms trafficking, with reports of other significant activities including environmental crime, money laundering and vice-related activities such as gambling and prostitution (Schloenhardt, 2006). There are reports of Chinese nationals participating in all such criminal endeavours (AFP, 2006; Lindley \& Beacroft, 2011; McCusker, 2006; Squires, 2005).

Whilst it is difficult to ascertain the morphology of these Chinese nationals engaged in criminal activity in the Pacific Islands, many have international links that are exploited in the furtherance of their activities. For example, a large methamphetamine laboratory discovered near Suva, Fiji in 2004 was being run by local Fijians (including Fijian Chinese) and a Hong Kong Chinese, with the operation apparently financed through Hong Kong. No specific triad group has been identified. There are also examples of Chinese nationals in the region facilitating human trafficking from their native provinces in China (Lindley \& Beacroft, 2011, p. 3). 
There is also evidence of other criminal groups operating within the Pacific region. In December 2011, it was reported that the Speaker of the Tongan Parliament had been implicated in assisting a Colombian national relocate to Tonga; this Colombian national was alleged to be a member of a transnational drug syndicate and his purpose for being in Tonga was to coordinate the transit of cocaine from South America, using Tonga as a transit destination for markets in Australia and China (McKenzie \& Baker, 2011).

PICs also have home grown criminal gangs such as the Rascals in the PNG. Though the level of organisation of these gangs is unclear, they are recognised as a crime threat (Fickling, 2004). This is particularly true in PNG and the Solomon Islands where these gangs have conducted bank robberies, arms trafficking, drug cultivation and trafficking and card skimming (Schloenhardt, 2006). Goddard (2005) notes the traditional view that such activities are reflections of underdeveloped economies and/or perceived social inequalities. However, he suggests such crimes in PNG may be motivated by local gift culture (Goddard, 2005, p. 110) and notes that the proceeds of social activities (including crime) are shared "to enhance prestige, repay gift-giving and engender future obligation."

Gang activity is also prominent in New Zealand, though the number of members in these gangs is not clear (Refugee Review Tribunal, 2009). An estimated 30 adult gangs currently operate throughout New Zealand and are involved in diverse and far-reaching criminal activity including illicit drug trafficking, burglary and theft, extortion, environmental crime and are characterised by their use of significant violence. This violence is generally directed at other gang members and is used to facilitate criminal activities or related to territorial disputes (New Zealand Government, 2010; Refugee Review Tribunal, 2009). Youth gangs also engage in illicit drug distribution, burglary and vehicle-related crime in New Zealand and may act as 'feeders' into adult gangs (Gower, 2008).

Two significant adult gangs in New Zealand are the Mongrel Mob (established in the mid-1960s in Hastings) and Black Power (established around 1970 in Wellington), which are both dominated by Pacific Islanders and Maoris (Bellamy, 2009, p. 2). These groups share similarities with OMCGs in their organisation and structure (specifically, their use of 'chapter' or local level divisions or operations), use of colours/patches to delineate membership and specific areas of territorial operation (Refugee Review Tribunal, 2009). 
The exact number of members of these groups is also unknown, but a combined figure (for Mongrel Mob and Black Power) of 2,600 was estimated in 2007. It was also estimated that this membership was spread across 145 chapters throughout New Zealand (Callinan, 2007). Interestingly, there is some evidence of aspirations for international expansion by the Mongrel Mob. In the 1980s, they tried to establish a chapter in Perth, Western Australia but were unsuccessful after being targeted for violence and intimidation by local OMGs such as the Coffin Cheaters (Refugee Review Tribunal, 2009).

Other migrant ethnic-based organised crime groups operate in the region, including a number of prominent groups in Australia that tend to be active in specific areas of criminality. The Romanians have a lengthy involvement in drug trafficking in Australia (ACC, 2011; CMC, n.d.). Lebanese groups have been active in illicit drug trafficking (especially hashish) and extortion in Australia since the 1960s (Morton \& Lobez, 2007). Similarly, Vietnamese groups have had long-standing involvement in drug trafficking including heroin and cannabis. Infamous groups such as the ' $5 \mathrm{~T}^{\prime}$ dominated criminal activity (including drug trafficking, extortion, illegal gaming) in parts of Sydney (Australian Broadcasing Corporation, 1997). Generally organised crime groups in Australia “...continue to evolve from being communally based, strongly hierarchical and easily defined by ethnicity or ethos, towards more flexible, loosely associated and entrepreneurial networks" (ACC, 2007).

\section{Transnational Offences}

\section{Illicit Drugs}

The most significant organised crime threat in the Oceanic region is the illicit drug industry. Whilst the scale of this issue is relatively low compared to other global regions, the illicit market remains locally significant. Also, Oceania ranks significantly globally in terms of prevalence rates, with one of the highest prevalence rates of the use of amphetamine type stimulants (ATS) and cannabis in the world. Australia and New Zealand are the target markets for drug importation in the region. Most importation is for ATS and precursor chemicals such as (pseudo) ephedrine from Europe, India and China, heroin from West and South East Asia and cocaine from South America. Cannabis is grown and transported within the region (UNODC, 2011b).

Cannabis is easily available in Australia and the market is supplied predominantly by local crops (McLaren \& Mattick, 2007, p. 26). It is the most common illegal drug in Australia, with about one third of 
the community estimate to have admitted to use of cannabis (Tresidder \& Shaddock, 2008). Similarly, cannabis is grown extensively in New Zealand in sufficient supply to meet the entire home demand for the drug (Wilkins \& Casswell, 2003). The second most common drug in Australia is MDMA with 22\% of 20-29 year olds claiming to have used it; one of the highest rates in the world (APAIC, 2009a). Australians pay a much higher price for the drug than customers in other Western Countries. This premium attracts suppliers to the market (AFP, n.d.-c). New Zealand also has one of the highest rates of use of ATS in the world (APAIC, 2009b). Precursor chemical demand has even been met by the importation of ContacNT, a Chinese drug with concentrated levels of pseudoephedrine. New Zealand Customs Service estimates that 10 million tablets were imported in 2008. However, pill shopping is still prevalent among younger age groups (Stringer, 2009).

Since the turn of the century, ATS have taken over the market from opiates in Australia, with speed, the powder form of the drug, being the most common variant. However, usages rates are comparatively low at $2-4 \%$ of the population (APAIC, 2009a). Interestingly, only $3 \%$ of police detainees use MDMA (ecstasy) compared with $21 \%$ using other forms of ATS; a reversal of the trend in the general population (APAIC, 2009a). Once again most of the market is supplied from producers within the country, while crystal methamphetamines are imported from Canada and south east Asia (AFP, n.d.-a). Only $2 \%$ of New Zealanders use ATS and are supplied mostly by local producers (APAIC, 2009b).

Heroin is still used in both countries even though its market share has fallen following a fall in availability. It is now only used by an estimated $0.2 \%$ of Australians (APAIC, 2009a). Unlike Europe and North America, Australia and New Zealand are supplied from the Golden Triangle in South East Asia (AFP, n.d.-b). Cocaine also has a very small market in Australia with only $1 \%$ of the population using the drug (APAIC, 2009a) but there are signs of an increase in use of cocaine along with availability (AAP, 2009; Ross, 2007).

The PICs suffer from under-resourced police services and high levels of corruption amongst politicians and public officials may occur (Rolfe, 2004, p. 7). This makes them attractive locations to operate drug redistribution, and grow and/or manufacture such drugs as well provide money laundering facilities (Reid, Devaney, \& Baldwin, 2006). 
Tran-shipment of drugs assists drug syndicates by allowing them to disguise the point of origin of their cargo. This can take place on land or at sea. "Some five thousand vessels cross the region on any given day. Large shipments can be transferred from a mother ship into smaller boats that speed to isolated atolls to await transit to the next destination." (Windybank, 2008, p. 33) Due to the geographic proximity to the PIC's, Asian organized crime gangs are involved in drug operations in the region (Rolfe, 2004, p. 7). Similarly, South American gangs are involved in tran-shipment of cocaine via the Pacific (Ranmuthugala, 2002, p. 179). Drugs seized in Fiji are usually destined for Australia and New Zealand. In $2000,357 \mathrm{~kg}$ of heroin was seized in Suva. The shipment was associated with Chinese nationals. The large methamphetamine seizure in 2004was organized by ethnic-Chinese Fijian citizens and potentially involved corrupt immigration and customs officials (The Age, 2004). As noted are no reliable figures on how much tran-shipment is occurring (SFADTRC, 2010, pp. 59-60). The prime target markets for drugs in Pacific are the large Western economies such as the United States, Canada, Australia and New Zealand (AFP, 2005, p. 7; Windybank, 2008, p. 33). The PIC's currently have very low levels of drug use among the population, although there are signs that ATS, notably "ice" is becoming popular throughout the region, particularly with Rascal gangs in PNG (Windybank, 2008, p. 34).

An indication of the scale of drug manufacture can be found in the discovery of a large methamphetamine factory in Suva, Fiji in 2004. At the time, this was the largest methamphetamine lab found in the southern hemisphere. This factory's ATS production was distributed to Europe, the United States, Australia and New Zealand. It was capable of producing approximately $500 \mathrm{~kg}$ of methamphetamine each week (Associated Press, 2004). Yet, the most common illicit drug activity in the Pacific remains the cultivation of cannabis which can be grown all year round in the equatorial Pacific climate (Ranmuthugala, 2002; Reid, et al., 2006). Most cannabis cultivation is for domestic consumption, however, there is an increasing involvement of organized crime. Most extensive cultivation of cannabis occurs in the PNG and Fiji. Most of the trade in cannabis is from PIC's to the large Western markets, and there have been documented cases of trades of guns from Indonesia, Southeast Asia and Australia for cannabis from the PNG (Reid, et al., 2006, p. 649).

\section{People Smuggling}

The PICs also play a role in people smuggling to the south-west Pacific (Australia and New Zealand) and north-eastern Pacific (Canada and the United States of America). Australia is the primary target for people smugglers in Oceania. It has a reputation for taking refugees and a very high percentage of those 
who arrive and claim refugee status are resettled with the majority staying in Australia. It is one of the top three refugee resettlement countries in the world and allocates places to refugees who are able to reach Australian territory (by boat or plane) under a Special Humanitarian Program (Parliamentary Library, 2011).

In the last decade most smuggled persons arriving in Australia were from the Middle East, who travelled overland or by plane and transited through Indonesia. They usually had a visa to visit Indonesia and some had their entire trip organized by the smugglers (United Nations Office on Drugs and Crime, 2011a, pp. 18-19).

People smuggling is facilitated through the PIC's. It is relatively easy to enter a PIC and obtain a passport. In some countries, such as PNG, there have been cases of public officials selling passports illegally. "In 2002 the database and passport-making machine were stolen from Papua New Guinea's immigration department. It was an inside job. Of twelve officials implicated in the scam, only one was charged. Not long after, streams of Chinese migrants began arriving" (Windybank, 2008, p. 35). However, other PIC's openly sell passports as a means of obtaining foreign currency. Tonga raised $\$ 20$ million from such a program (Rolfe, 2004, p. 8). Travellers, once in a nation such as Fiji, have in the past found it is easier to obtain a visa to Australia, than from their home country (FBC, 2010). In addition, passport and identity fraud are used to support people smuggling activities (AFP, 2005, p. 7)

China is an often cited as a source country of illegal migrants into the PIC and organized crime groups allegedly facilitate the passage of Chinese illegal migrants. . The routes include going via Micronesia to get into the USA, PNG to get into Australia and Polynesia to get into New Zealand (Rolfe, 2004, p. 7). Chinese crime groups were thought to have prepared for such activities by sending associates to PICs in the late 1990s to facilitate people smuggling. Smugglees enter by overstays or false passports, although some use bribery to buy citizenship. Many intend to go on to Australia, though most Pacific islands are transit points to the US and Canada (Windybank, 2008, pp. 34-35).

\section{People Trafficking}

People trafficking in Oceania provides for both the sex and construction business. Most people trafficked in Australia, New Zealand is associated with sex trafficking. In Australia, the majority of trafficked sex workers end up in Sydney. A 2004 estimate stated that between 300 and 1000 women are 
trafficked into Australia each year (Phillips, 2008, p. 3). Arrests and convictions for trafficking offences are however, relatively infrequent and over several years (2004-2008) as few as 34 prosecutions undertaken (David 2008, 2010). Most of these women come from Southeast Asia and China, are typically brought to the country on legitimate student or holiday visas, and then employed in legal and illegal brothels around the country (David, 2008, 2010; Phillips, 2008, p. 3).

In recent years Australian states and territories have legalized prostitution. One of the outcomes of this has been a reduction in organized crime involvement in prostitution. At present, there is little evidence of organized crime in the legal sex industry on the Australian Gold Coast, which is a major tourist location (CMC, 2011). There are growing numbers of Asian women in the illegal sex industry but no evidence that they are trafficked. Charges were laid in 2009 against Chinese, South Korean and Thai nationals for organized illegal prostitution but not sex trafficking. "Most of the organizers of Asian prostitution detected by PETF [Prostitution Enforcement Task Force] are from the same country as the sex workers, or at least speak the same language, but there have been some cases of Australian-born organizers operating a number of Asian sex workers." (CMC, 2011, p. 21) There is no information as to the number or the scale of operations involving the forced labour of trafficked people in Australia. However, this does not include situations where foreign visitors on work visas are exploited once in the country; for example, being invited to stay to work under false claims of wages and working conditions (Lindley \& Beacroft, 2011, p. 3; Phillips, 2008, pp. 11-12).

PICs are used as transit points for trafficking to other target nations but few end up in Australia because of relatively effective border controls (Larson, 2010, p. 5; Lindley \& Beacroft, 2011). There is evidence of people being brought into PICs by legal and illegal means, usually by facilitators (both organised crime and small-scale operators) outside of the country. Most of the trafficking is either between islands or from Asia to the PIC's, and often for sex work (Lindley \& Beacroft, 2011, pp. 3-4; Sasako, 2007). There have also been reports of child sexual exploitation associated with the logging industry in the PICs, where children are sexually exploited as prostitutes in logging camps (Larson, 2011).

\section{Illegal Weapons Smuggling}

Australia and New Zealand have very strict firearm laws and relatively small markets for illegal firearms. However, there is weak law and order capacity in PNG, which facilitates illegal activity. In the PNG, firearms, both modern high powered models and homemade, are used in ethnic and tribal fighting, 
robberies, extortion and intimidation, including during elections (Singirok, 2005). Most of the illegal weapons are concentrated in the Enga and the Southern and Western Highlands and most armed crime occurs in the cities and Highlands (Singirok, 2005, p. 2). Parliamentarians also use guns to intimidate voters and other MPs. The situation was so common that in 2004, Parliament was suspended due to the concern that high-powered weapons were on parliamentary grounds. Illegal ownership and sale of guns and ammunition are encouraged by weak gun registration laws and practice and the high tariff on weapons and bullets which in turn makes it uneconomic to sell them through legitimate retail outlets (Singirok, 2005, pp. 4-5). Guns are also available due to poor management of military and police arsenals. It is easy to bring guns into PNG from Australia through the Torres Strait and the 'dogleg' region between PNG, Australia and Indonesia. Demand is also driven by rebel groups in West Papua (Irian Jaya) and the Solomon Islands (Singirok, 2005). In the Solomon Islands militia groups obtained the police armouries in Auki and Guadalcanal (Senate Foreign Affairs Defence and Trade References Committee (SFADTRC), 2010, p. 15). The Solomon Islands is still heavily supplied by guns and grenades left over from the Second World War (Singirok, 2005).

\section{Financial Crime}

Financial crime takes two forms: economic crime targeting the finances of victims and use of the financial system to disguise profits from criminal activity. Financial crime is an increasing sophisticated criminal activity, driven in part by the rapid expansion of e-commerce and consequently manifest in Oceania as well. The small size of the PIC populations and inexperience of governments has led to nations becoming victims of financial scams including unprofitable mines and in one case, a musical (Ranmuthugala, 2002, p. 178).

The involvement of organized crime in these activities is unclear as the majority of known offenders were individuals not associated with organized crime. Detailed data is not available on the extent of financial crime, for example, there is very little information about money laundering on the public record as investigators do not release detailed information on cases (CMC, 2009, p. 11). A decade ago there was extensive offshore banking in the PICs with some earning the dubious reputation as safe havens for tainted wealth. The under-regulated financial services that once proliferated in PICs such as Vanuatu, Nauru and Fiji have all been closed with international assistance following blacklisting by the Financial Action Task Force (FATF). PICs are still avenues for money laundering (Senate Foreign Affairs Defence and Trade References Committee (SFADTRC), 2010, p. 61). A 2008 estimate put the value of 
money laundering transactions in Australia at between $\$ 2$ billion and $\$ 4.5$ billion per year (Choo, 2008, p. 3).

Excise avoidance is common throughout the region. The most lucrative product is smuggled tobacco from Southeast Asia into the high tobacco tax nations of Australia and New Zealand. Raw tobacco or 'chop-chop' is available from nations such as the Philippines and can fetch a 10,000\% profit when sold in Australia with minimal risk of apprehension or a prison term. Tobacco is also smuggled in its processed form as cigarettes, both legitimately branded and counterfeit. Most smugglers of tobacco are also involved in "drugs, money laundering, identity fraud, and car re-birthing" (Scollo \& Winstanley, 2008).

\section{Cyber Crime}

In Australia in 2010-11, 6.2 million households had broadband access (ABS, 2011). While this brings many social benefits, it also increases Australia's exposure to cyber crime. Australia is subject to the full gamete of cybercrime including hacking, malware, Botnets, DDoS attacks, phishing and spam (HRSCC, 2010, p. 33). According to the Australian Institute of Criminology, $14 \%$ of Australian businesses were attacked at least once in 2006-07. However, Malware continues to be the predominant security threat to individuals and corporations in Australia (Choo, 2011, p. 2). There is also a continued presence of advance fee frauds being perpetrated via the internet (AFP, 2005). It is estimated that West African based advance fee fraudsters take $\$ 100$ million from Australia every year (Queensland Police Service 2010).

\section{Illegal Fishing}

Illegal fishing is a threat to the region (AFP, 2005) and ranges from a failure to comply with laws and regulations by commercial fishermen, through to illegal fishing by unregistered fishermen (Putt \& Nelson, 2008). Organised crime tends to concentrate on the trade in high-value seafood (rock lobster, abalone and shark-fin in Australia) and the provision of seafood products that are not legally on the market (Putt \& Nelson, 2008).

It is difficult for small PICs to prevent illegal fishing in their Exclusive Economic Zones (EEZ), making illegal fishing a significant transnational crime in the region. It takes the form of authorized fishing vessels operating outside the terms of their license and unlicensed vessels fishing in the EEZs. PICs have small populations and vast areas of ocean in their EEZs. PNG has 19 square kilometres of sea for every 
one square kilometre of land; Tuvalu has almost 28,000 square kilometres of seas for every square kilometre of land (SFADTRC, 2010, pp. 55-57) both are under-equipped to police these zones.

\section{Conclusion}

Oceania has a relatively low level of crime prevalence yet in the smaller and under-developed PICs we have shown that transnational crime has become increasingly common. A risk contained but potentially dangerous if state failure or fragility undermines law enforcement capacities. We predict that as the pace of globalisation quickens and the demand for raw materials and resources grows some parts of the Pacific will be prone to criminal enterprises run by both indigenous and foreign crime groups. Australia and New Zealand will remain attractors of illicit goods notably ATS but will in turn be source countries for diminishing fish stock such as beche de mere and abalone as well forest timber. Finally the role of states such as Australia and New Zealand in helping to maintain law enforcement capacities throughout the region will be crucial if organized crime in Oceania is to be kept in check while demand for illicit resources grow.

\section{References}

AAP. (2009). Cocaine use rising in Australia: report. Retrieved 14 June 2012 http://news.theage.com.au/breaking-news-national/cocaine-use-rising-in-australia-report20090612-c541.html

Asia \& Pacific Amphetamine-Type Stimulants Information Centre (APAIC). (2009a). Australia. Retrieved 10 March 2012, from United Nations Office on Drugs and Crime http://www.apaic.org/index.php?option $=$ com content\&view $=$ article\&id $=132 \&$ Itemid $=14$ $\underline{0}$

Asia \& Pacific Amphetamine-Type Stimulants Information Centre (APAIC). (2009b). New Zealand. Retrieved 10 March 2012, from United Nations Office on Drugs and Crime http://www.apaic.org/index.php?option $=$ com content\&view $=$ article\&id $=134 \& I t e m i d=14$ $\underline{2}$

Associated Press. (2004). 'Southern Hemisphere's biggest meth lab' smashed (news item). Retrieved 7 February 2012 http://www.taipeitimes.com/News/world/archives/2004/06/10/2003174485

Australian Broadcasing Corporation (Writer). (1997). Cabramatta, Four Corners. Australia. Australian Bureau of Statistics (ABS). (2011). 8146.0 Household Use of Information Technology, Australia, from http://www.abs.gov.au/AUSSTATS/abs@.nsf/Latestproducts/8146.0Media\%20Release1 2010-11?opendocument\&tabname $=$ Summary\&prodno $=8146.0 \&$ issue $=2010$ $11 \&$ num $=\&$ view $=$ 
Australian Crime Commission (ACC). (2007). Submission to the Parliamentary Joint Committee on the Australian Crime Commission: Inquiry into the future impact of serious and organised crime on Australian Society. Canberra: Australian Crime Commission.

Australian Crime Commission (ACC). (2011). Outlaw Motorcycle Gangs. Retrieved 8 March 2012, from Australian Crime Commission http://crimecommission.gov.au/sites/default/files/files/omcgs.pdf

Australian Crime Commission (ACC). (2012). How serious is the threat posed by outlaw motorcycle groups? Retrieved 28 February 2012, from Australian Crime Commission www.crimecommission.gov.au/node/71

Australian Federal Police (AFP). (2005). A new network in the Pacific. Platypus, 89, 5-7.

Australian Federal Police (AFP). (2006). Submission 16: Inquiry into Australia's aid program in the Pacific. Submission to Parliamentary Inquiry. Australian Federal Police. Canberra.

Retrieved from http://www.aph.gov.au/Parliamentary_Business/Committees/House of Representatives Committees?url=/jfadt/pacificaid/subs.htm

Australian Federal Police (AFP). (n.d.-a). Amphetamines. Retrieved 10 March 2012, from Australian Federal Police http://www.afp.gov.au/policing/drug-crime/amphetamines.aspx

Australian Federal Police (AFP). (n.d.-b). Heroin. Retrieved 10 March 2012, from Australian Federal Police http://www.afp.gov.au/policing/drug-crime/heroin.aspx

Australian Federal Police (AFP). (n.d.-c). MDMA. Retrieved 10 March 2012, from Australian Federal Police http://www.afp.gov.au/policing/drug-crime/mdma.aspx

Ayling, J., \& Broadhurst, R. (2012). Organized crime in Australia and New Zealand. In L. Paoli (Ed.), Oxford Handbook of Organized Crime. Oxford: Oxford University Press.

Barker, T. (2011). American Based Biker Gangs: International Organized Crime. American Journal of Criminal Justice, 36, 207-215.

Bashir, M. (2010, 25 March 2010). Chinese Stunned, Papua New Guinea Post Courier.

Bellamy, P. (2009). Young People and Gangs in New Zealand. Retrieved 1 March 2012, from New Zealand Parliament http://www.parliament.nz/enNZ/ParlSupport/ResearchPapers/b/c/7/00PLSocRP09021-Young-people-and-gangs-inNew-Zealand.htm

Broadhurst, R., Gordon, A., \& McFarlane, J. (2012). Transnational and Organised Crime in the Indo-Asia Pacific. In F. Alum \& S. Gilmour (Eds.), Handbook of Transnational Organised Crime (pp. 143-156). London: Routledge.

Browne, C. (2006). Pacific Island Economies. Washington, DC: International Monetary Fund.

Callick, R. (2010, 5 January 2010). Triads arrested after PNG shooting, The Australian.

Callinan, R. (2007, 5 July 2007). Tribal Trouble, Time. Retrieved from http://www.time.com/time/magazine/article/0,9171,1640583,00.html

Choo, K.-K. (2008). Money laundering risks of prepaid stored value cards. In J. Putt (Ed.), Trends \& Issues in crime and criminal justice. Canberra: Australian Institute of Criminology.

Choo, K.-K. (2011). Cyber threat landscape faced by financial and insurance industry. In A. Tomison (Ed.), Trends \& issues in crime and criminal justice Canberra: Australian Institute of Criminology.

Crime and Misconduct Commission (CMC). (2009). Money laundering and organised crime in Queensland Crime Bulletin Series. Brisbane: Crime and Misconduct Commission. 
Crime and Misconduct Commission (CMC). (2011). Regulating Prostitution: a follow-up review of the Prostitution Act 1999. Brisbane: Crime and Misconduct Commission.

Crime and Misconduct Commission (CMC). (n.d.). Submission to the Parliamentary Joint Committee on the Australian Crime Commission: Inquiry into the future impact of serious and organised crime on Australian society. Retrieved 2 March 2012, from Crime and Misconduct Commission

www.aph.gov.au/Parliamentary_Business/Committees/Senate_Committees?url=acc_ctte/ completed_inquiries/2004-07/organised_crime/submissions/sublist.htm

David, F. (2008). Trafficking of women for sexual purposes Research and Public Policy Series. Canberra: Australian Institute of Criminology.

David, F. (2010). Labour Trafficking Research and public policy series. Canberra: Australian Institute of Criminology.

FBC. (2010). Fiji crackdown on illegal immigrants (news item). Retrieved 7 February 2012, from Radio Fiji http://www.radiofiji.com.fj/fullstory.php?id=25737

Fox, L. (2012). PNG's Constitutional crisis set to continue. Retrieved 14 June 2012, from Australian Broadcasting Commission

Goddard, M. (2005). Unseen City: Anthropological perspectives on Port Moresby, Papua New Guinea. Canberra: Pansanus Books.

Gower, P. (2008, 19 January 2008). Gang presence growing since early days in Otara, The New Zealand Herald.

House of Representatives Standing Committee on Communications (HRSCC). (2010). Hackers, Fraudsters and Botnets: Tackling the Problem of Cyber Crime. Canberra: Parliament of the Commonweatlh of Australia.

Larson, J. (2010). Migration and people trafficking in southeast Asia. In A. Tomison (Ed.), Trends \& issues in crime and criminal justice. Canberra: Australian Institue of Criminology.

Larson, J. (2011). The trafficking of children in the Asia-Pacific. In A. Tomison (Ed.), Trends \& issues in crime and criminal justice. Canberra: Australian Institute of Criminology.

Lindley, J., \& Beacroft, L. (2011). Vulnerabilities to trafficking in person in the Pacific Islands. In A. Tomison (Ed.), Trends \& issues in crime and criminal justice. Canberra: Australian Institute of Criminology.

McCusker, R. (2006). Transnational crime in the Pacific Islands: real or apparent danger? In T. Makkai (Ed.), Trends \& Issues in crime and criminal justice (pp. 6). Canberra: Australian Institute of Criminology.

McKenzie, N., \& Baker, R. (2011, 17 December 2011). Tongan Speaker helped drug team, say police, Sydney Morning Herald.

McLaren, J., \& Mattick, R. (2007). Cannabis in Australia - Use, supply, harms and responses Monograph series. Sydney: Australian Government Department of Health and Ageing.

Morton, J., \& Lobez, S. (2007). Gangland Australia. Melbourne: Victory Books.

New Zealand Government. (2010). Organised Crime in New Zealand. Retrieved 1 March 2012, from New Zealand Government www.ofcanz.govt.nz/publications/organised-crime-newzealand-2010

Newman, G. (Ed.). (1999). Global Report on Crime and Justice. New York.

Oakes, D. (2012). Bikie gangs expanding into south-east Asia. Retrieved 14 June 2012 http://www.theage.com.au/national/bikie-gangs-expanding-into-southeast-asia20120314-1v31k.html\#ixzz1xAtiN8iY 
Organised \& Financial Crime Agency New Zealand (OFCANZ). (2011). Rebels not welcome here (Press Release). Retrieved 4 June 2012, from OFCANZ http://www.ofcanz.govt.nz/publications

Parliamentary Joint Committee on the Australian Crime Commission. (2007). Inquiry into the future impact of serious and organised crime on Australian society. Canberra: Senate.

Parliamentary Joint Committee on the Australian Crime Commission (PJCACC). (2007). Inquiry into the future impact of serious and organised crime on Australian society. Canberra: Senate Printing Unit.

Parliamentary Library. (2011). Refugee resettlement to Australia: what are the facts? Background Note. Canberra: Parliament of Australia.

Phillips, J. (2008). People trafficking: an update on Australia's response Research Paper. Canberra: Parliamentary Library.

Putt, J., \& Nelson, D. (2008). Crime in the Australian fishing industry. In J. Putt (Ed.), Trends \& Issues in crime and criminal justice. Canberra: Australian Institute of Criminology.

Quinn, J. F., \& Forsyth, C. (2011). The Tools, Tactics, and Mentality of Outlaw Biker Wars. American Journal of Criminal Justice, 36, 216-230.

Ranmuthugala, D. (2002). Security in the South Pacific: the law enforcement dimension. Platypus(77), 10-17.

Refugee Review Tribunal. (2009). Country Advice - New Zealand. Canberra: Australian Government.

Reid, G., Devaney, M., \& Baldwin, S. (2006). Drug production, trafficking and trade in Asia and Pacific Island countries. Drug and Alcohol Review, 25, 647-650.

Robertson, J. (2012). Australian bikies Hells Angels and Bandidos club members own nightspots in Thailand tourist centres. Retrieved 14 June 2012 http://www.news.com.au/australianbikies-hells-angels-and-bandidos-club-members-own-nightspots-in-thailand-touristcentres/story-e6freoof-1226166279473

Rolfe, J. (2004). Oceania and Terrorism: Some Linkages with the Wider Region and the Necessary Responses Working Paper. Wellington: Centre for Strategic Studies.

Ross, J. (2007). Illicit drug use in Australia: Epidemiology, use patterns and associated harm (2nd ed.). Canberra: National Drug \& Alcohol Research Centre.

Sasako, A. (2007). Are the Chinese Triads taking over Honiara? Retrieved 10 March 2012 http://www.islandsbusiness.com/islands_business/index_dynamic/containerNameToRepl $\underline{\text { ace }=\text { MiddleMiddle } / \text { focusModuleID }=17965 / \text { overideSkinName }=\text { issueArticle-full.tpl }}$

Schloenhardt, A. (2006). Drugs, Sex and Guns: Organised Crime in the South Pacific. In N. Boister \& A. Costi (Eds.), Regionalising International Criminal Law in the Pacific (pp. 159-184). Wellington: NZACL/ALCPP.

Scollo, M. M., \& Winstanley, M. H. (2008). Tobacco in Australia: Facts and Issues (3rd ed.). Carlton, Vic: Cancer Council Victoria.

Senate Foreign Affairs Defence and Trade References Committee (SFADTRC). (2010). Security challenges facing Papua New Guines and the island states of the southwest Pacific. Canberra: Senate.

Singirok, J. (2005). The Use of Illegal Guns: Security Implications for Papua New Guinea State Society and Governance in Melanesia. Canberra: Research School of Pacific and Asian Studies, ANU. 
Spapens, T. (2010). Macro Networks, Collectives, and Business Processes: An Integrated Approach to Organized Crime. European Journal of Crime, Criminal Law and Criminal Justice, 18, 185-215.

Squires, N. (2005, 26 February 2005). South Pacific islands seen as soft touch by Chinese gangsters, South China Morning Post.

Stringer, D. (2009). The National Drug Intelligence Bureau Battling Against Billion Dollar 'P' Trade. Retrieved 24 February 2012, from New Zealand Police Association http://www.policeassn.org.nz/newsroom/publications/featured-articles/-national-drugintelligence-bureau-battling-against-billion-

The Age. (2004). Pacific an ideal launch pad for drugs. Retrieved 15 February 2012, from Fairfax Ltd http://www.theage.com.au/articles/2004/06/19/1087595786691.html?from=storylhs

Transparency International. (2011). Corruption Perception Index 2011. Retrieved 8 March 2012, from Transparency International http://cpi.transparency.org/cpi2011/results/

Tresidder, J., \& Shaddock, C. (2008). Policing and cannabis use in Australia. Retrieved 10 March 2012, from National Cannabis Prevention and Information Centre http://ncpic.org.au/ncpic/publications/aic-bulletins/article/policing-and-cannabis-use-inaustralia

United Nations. (n.d.). Oceania. Retrieved 8 March 2012, from United Nations http://www.un.org/migration/presskit/factsheet oceania.pdf

United Nations Office on Drugs and Crime. (2011a). Smuggling of Migrants by Sea. Vienna: United Nations Office on Drugs and Crime.

United Nations Office on Drugs and Crime. (2011b). World Drug Report 2011. New York: United Nations Office of Drugs and Crime.

Veno, A., \& Gannon, E. (2010). The Brotherhoods: Inside the Outlaw Motorcycle Clubs (Full Throttle Edition). Crows Nest, NSW: Allen \& Unwin.

Veno, A., \& van den Eynde, J. (2008). Submission 10: Parliamentary Joint Committee on the Australian Crime Commission Inquiry into the legislative arrangements to outlaw serious and organised crime groups. Canberra.

Wilkins, C., \& Casswell, S. (2003). Organized crime in cannabis cultivation in New Zealand: an economic analysis. Contemporary Drug Problems, 30 (Winter 2003), 757-777.

Windybank, S. (2008). The Illegal Pacific, Part 1: Organised Crime. Policy, 24(2), 32-38. 